\author{
Weronika Majek \\ Uniwersytet Gdański \\ ORCID ID: https://orcid.org/0000-0001-7824-138X
}

\title{
Zrozumieć tajemnice codzienności
}

[recenzja książki Studies of the Cultural and Bioethical Aspects of Life in Contemporary Asia]

Understanding the secrets of everyday life [book review Studies of the Cultural and Bioethical Aspects of Life in Contemporary Asia]

Понять секреты повседневной жизни [рецензия книги Studies of the Cultural and Bioethical Aspects of Life in Contemporary Asia]

\footnotetext{
7 biór badań dotyczących życia we współczesnej Azji to pozycja przyciągająca uwagę i w ciekawy sposób prezentująca zagadnienia kulturowe i bioetyczne w szerokiej perpektywie humanistycznej. Książka o interesującym tytule okazała się nie tylko zaskakująco aktualna, ale także pozwala na uporządkowanie tematyki pozornie rozproszonej, bo zamkniętej jedynie naukowym nawiasem regionu geograficznego. Czytelnik ma szansę na zaznajomienie się z problematyką kulturowych podstaw decyzji biopolitycznych w takich krajach, jak Filipiny i Tajlandia; z krytycznym przeglądem zmian zachodzących w zakresie edukacji publicznej na przykładzie Indii oraz edukacji ekonomicznej na przykładzie Wietnamu; z opisem systemów zdrowotnych w ujęciu arabskim i rumuńskim oraz otrzymuje pogłębioną analizę zarówno starożytnych, jak i współczesnych aspektów kultury w odniesieniu
} 
do antycznego subkontynentu indyjskiego oraz nowoczesnej Japonii, a także opis politycznego ustroju Laosu.

Autorzy reprezentują wiele różnych środowisk badawczych, a przyjęta przez nich metodologia nie pozwala czytelnikowi się nudzić. Trafimy na analizy przekrojowe, badania własne oraz sprawozdania $\mathrm{z}$ aktualnego stanu wiedzy w wybranym temacie, a prezentowane są one przez młodych naukowców z Polski, Rumunii, Wietnamu i Indii. Autorzy z wielu ośrodków naukowych mają za sobą różne doświadczenia, przez co pozycja jest oryginalna i niecodzienna, o czym możemy się dowiedzieć już we wstępie przygotowanym przez redaktor Marszałek-Kawę. Choć osią łączącą poszczególne rozdziały jest region azjatycki, to część autorów podejmuje próbę porównania go z realiami Zachodu, co w rezultacie pozwala nam uzyskać informacje o aborcji w Polsce (na tle sytuacji w Tajlandii) w rozdziale drugim czy o kierunkach rozwoju służby zdrowia w Rumunii (w kontekście Arabii Saudyjskiej), co z kolei ujęte zostało w rozdziale czwartym. Badacze, przy pracy nad swoimi tekstami, posłużyli się wieloma narzędziami jakościowymi, w tym: badaniami terenowymi, standaryzowanymi wywiadami, kwestionariuszami, badaniami porównawczymi i wywiadem pogłębionym. Pod tym względem najbardziej wyróżnia się rozdział piąty, poświęcony badaniom wpływu czynników demograficznych na umiejętności w zakresie rozumienia zagadnień ekonomicznych i finansowych wśród mieszkańców wiejskich obszarów Wietnamu. Autorzy Phung Thanh Quang i Khuc The Anh z Uniwersytetu w Hanoi prezentują dokładny przegląd narzędzi metodologicznych służących do badania wspomnianej korelacji, modyfikują je w uzasadniony sposób w celu przeprowadzenia własnych badań ankietowych oraz w czytelny sposób relacjonują efekty swojej pracy.

Należy docenić, że cytowane przez autorów publikacje i prezentowane badania (zarówno cudze, przywoływane, jak i własne) są aktualne i rzetelne. Każdy z rozdziałów odsłania przed czytelnikiem nowy fragment kulturowej rzeczywistości w różnych perspektywach. W tekście Agaty Strządały z Uniwersytetu w Opolu bardzo ciekawie zestawione zostały takie aspekty, jak model rodziny, nepotyzm, transparentność podejmowania profesjonalnych decyzji medycznych czy szacunek dla pacjenta na przykładzie podejścia zachodniego i obecnego w kulturze współczesnych Filipin. Trafnie dobrane 
studia przypadków wyjątkowo klarownie ukazują jak odmiennie oceniane będą zachowania lekarzy przez pacjentów oraz instytucje prawne w państwach Zachodu i na wyspach republiki Filipin.

Warto nabyć tę pozycję chociażby po to, aby ujrzeć zagadnienia etyczne i moralne związane $\mathrm{z}$ zawodami medycznymi w zupełnie innym świetle. Niemniej jednak rzuca się w oczy fakt, że choć w abstrakcie i wśród wymienionych hipotez badawczych możemy znaleźć stwierdzenie, że filipińska bioetyka ma pewien znaczący wpływ na rozwój bioetyki w Afryce, to jednak w tekście taka teza nie znajduje uzasadnienia, żadnego przykładu czy odwołania do literatury z terenu Afryki; pojawia się jedynie w konkluzjach w tej samej formie, co na początku i nadal bez argumentów.

Bartosz Płotka z Uniwersytetu Mikołaja Kopernika w Toruniu omawia dwa zagadnienia z pogranicza etyki, biopolityki, prawa i medycyny: legalny i polityczny status aborcji (w ujęciu krytycznym na przykładzie Polski i Tajlandii) oraz macierzyństwo zastępcze w perspektywie tajskiej kultury i decyzji politycznych ujmowanych jako konsekwencja przekonań dominujących w opinii publicznej lokalnej społeczności. Systematyczne ujęcie podobieństw i różnic w rozwiązaniach prawnych regulujących zabiegi terminacji ciąży pozwala uporządkować temat. Autorowi udaje się wyjaśnić, w jakim zakresie tajski system prawny stoi w opozycji do dominującego światopoglądu buddyjskiego oraz potrzeb społecznych. Sprawa zastępczego macierzyństwa przedstawiona jest inaczej - poprzez analizę wpływów kulturowych autor ukazuje w jakim zakresie ta nieformalna instytucja przekształciła się na przestrzeni lat z powszechnie akceptowanej w uważaną za szkodliwą i niepożądaną. Interesującym zabiegiem jest umieszczenie problematyki w ujęciu biopolityki i ideologii biopolitycznej raczej, niż przedstawienie jej jako przykładu nieustrukturalizowanych usług medycznych.

Bardzo ciekawym rozdziałem jest opis etycznych i społecznych założeń rządów Ashoki na terenie Azji w trzecim wieku przed naszą erą. Uderzające są podobieństwa propagowanego przez Ashokę (Aśokę) stylu uprawiania władzy ze współczesnymi priorytetami prawa międzynarodowego, prawami człowieka, takimi jak prawo do życia, rzetelnego sądu, wolności słowa, myśli, sumienia i religii. 
Choć wszystkie rozdziały ukazują inny fragment rzeczywistości i z pewnością każdy dowie się czegoś nowego, poprzez zapoznanie się $\mathrm{z}$ aktualną literaturą i nietuzinkowymi ujęciami omawianej problematyki, to jednak publikacja ma kilka niedociągnięć. Uderzający jest brak konsekwencji w stosowaniu przypisów, w części artykułów spotkamy przypisy harwardzkie, w większości tekstów zastosowano cytowanie oksfordzkie. Niekonsekwencja redakcyjna nie utrudnia przyswojenia treści, jednak trudno o niej nie wspomnieć. Uważne oko znajdzie też kilka literówek, czy błędów w zdaniach, moim ulubionym przykładem jest pozostawienie w jednym z tekstów słowa wunderground, choć ewidentnie autor miał na myśli underground.

Najsłabszy metodologicznie wydaje się rozdział czwarty, w którym omówiona została służba zdrowia w Arabii Saudyjskiej i Rumunii, gdyż zawiera mało piśmiennictwa, a autorki z Uniwersytetu w Bukareszcie mogłyby nieco obszerniej uzasadnić dobór mierników skuteczności działania opieki zdrowotnej. Co więcej, dane wykorzystane do analiz pochodzą z lat 2010-2014, co sprawia że ostateczne wnioski mogą nie oddawać aktualnego stanu rzeczy.

Jednak mimo drobnych niedociągnięć książka ma dużą wartość dydaktyczną oraz naukową i z pewnością zainteresuje zarówno osoby, które chcą pogłębić swoją wiedzę na temat Dalekiego Wschodu, jak i dopiero rozpocząć przygodę z kulturą Azji. Największym plusem tej pozycji jest szeroki wachlarz dyscyplin naukowych wraz z typowym dla nich warsztatem, wykorzystany do ukazania różnych aspektów problematyki kultury, bioetyki i życia codziennego współczesnych państw azjatyckich. Od politologii, przez biomedycynę, etykę, zagadnienia ekonomiczne, aż po szerokie studia kulturoznawcze i kulturowe - zarówno specjaliści różnych dziedzin, jak i osoby zainteresowane specyfiką Wschodu znajdą w tej publikacji motywację do pogłębionej refleksji oraz krytycznej dyskusji akademickiej. Z niecierpliwością czekam na kolejne pozycje wydawane w ramach cyklu „Biblioteka Azji i Pacyfiku” toruńskiego wydawnictwa. 
MGR WERONIKA MAJEK

Instytut Filozofii, Dziennikarstwa i Socjologii

Wydział Nauk Społecznych

Uniwersytet Gdański

ul. Hallera 241, 80-502 Gdańsk.

wmajek11@gmail.com

\section{Bibliografia}

Marszałek-Kawa, J. (red.) (2018). Studies of the Cultural and Bioethical Aspects of Life in Contemporary Asia. Toruń: Wydawnictwo Adam Marszałek. 